\title{
Ferric Oxyhydroxide as Fouling Prevention Reagent for Low-Pressure Membranes
}

\author{
Marta Litynska ${ }^{1 *}$, Roman Antoniuk', Nataliia Tolstopalova' ${ }^{1}$ Igor Astrelin ${ }^{1}$ \\ 1 Faculty of Chemical Technology, National Technical University of Ukraine "Igor Sikorsky Kyiv Polytechnic \\ Institute", 37 Peremohy pr., Kyiv, 03056, Ukraine \\ * Corresponding author's e-mail: m.litynska-2017@kpi.ua
}

\begin{abstract}
Membrane technologies are very popular both in drinking water and wastewater treatment due to their significant advantages. However, colloidal fouling is one of the main disadvantages of low-pressure membranes. Fine particle ferric oxyhydroxide effectively protected membrane and adsorb humates, phosphates, arsenates, etc. Dividing of adsorption and microfiltration into two stages was the recommended regime. Mixing with adsorbent was the first one and separation on the membrane was the second stage. The adsorbent with immobilized impurities formed protective layer on the membrane surface. The non-adsorbed organic matter was left on this thickness. During backwash, water flow removed the adsorbent with immobilized pollutants. Afterwards, membrane was as clean as before filtration.
\end{abstract}

Keywords: microfiltration, adsorption, hybrid technology, natural organic matter, colour

\section{INTRODUCTION}

Membrane technologies are very popular both in drinking water and wastewater treatment due to their significant advantages, for example, high process automatization, small physical footprint, high efficiency, simple maintenance, etc. (Fane, Wang $\& \mathrm{Hu}, 2015)$. However, this treatment method has some disadvantages, especially fouling. There are different kinds of this process, especially colloidal fouling, organic fouling, inorganic scaling, biofouling (She et al., 2016), but colloidal fouling is the most unacceptable type (Sun et al., 2013).

Surface waters contain a lot of different organic components, among them humic compounds, fulvic complexes, microbial polysaccharides and others (Rosario-Ortiz, Snyder \& Suffet, 2007). Microorganisms (bacteria, algae) produce extracellular and cellular organic matter, which consists from high-MW ( $>100 \mathrm{kDa})$ polysaccharides, peptides/proteins, etc. (Pivokonsky et al., 2014). Humic and fulvic compounds are the result of biomass decay (Kleber et al., 2015). These high-molecular organic substances form gel layer on membrane surface and inside pores (Cai, Wee, \& Benjamin, 2013). This process is called colloidal and organic fouling.

Backwash and chemical enhanced backwash are used for cleaning membranes. However, in the case of colloidal fouling, backwash does not give sufficient result. Therefore, this gel layer can be removed only by chemical enhanced backwash (Sun et al., 2013). It reduces the work time of membranes and increases the consumption of chemicals for cleaning. Thus, it causes higher operation and maintenance costs. Hence, studies on new approaches in fouling protection are very expedient. Optimizing of hydraulic conditions of feed water can reduce external fouling (on the membrane surface), but do not have significant effect on the internal fouling (in pores) (She et al., 2016). Increasing of crossflow velocity (Sim et al., 2014), usage of pulsed flow (Blandin et al., 2016), air bubbling (Radaei et al., 2018), feed spacers (Siddiqui et al., 2017) are among these hydraulic methods of fouling prevention. However, it is significantly more difficult to avoid internal fouling (She et al., 2016). 
There are some novel methods of fouling prevention, for example, vibration unit (Shi \& Benjamin, 2009), (Su et al., 2018), or fine particle cover (Kim, Cai \& Benjamin, 2008), especially heated iron oxide particles (Kim, Deng \& Benjamin, 2008) or aluminium oxides (Liu et al., 2017). According to (Pivokonsky et al., 2014), ferric oxides and hydroxides at $\mathrm{pH}$ 6.0-7.7 effectively adsorb plankton cells and cellular organic matter. According to the previous studies, fine particle ferric oxyhydroxide may effectively adsorb humates (Litynska \& Maletskyi, 2017). Moreover, hybrid method permitted to remove pollutant ions, for example, arsenates, which are present in many natural waters. Thus, combination of this adsorbent and microfiltration or ultrafiltration membrane is very prospective.

\section{MATERIALS AND METHODS}

Iron (III) oxyhydroxide was precipitated from $\mathrm{FeCl}_{3}$ solution by thermal hydrolysis of urea. Synthesized adsorbent consisted from small particles with crystal structure of $\mathrm{FeOOH}$ (Litynska et al, 2018). Model water for humate adsorption experiments contained sodium salt of humic acid as colour component and $\mathrm{NaHCO}_{3}$ in concentration $5 \mathrm{~g} / \mathrm{l}$ as buffer component. The water $\mathrm{pH}$ was adjusted to 5.8 by $0.1 \mathrm{M} \mathrm{HCl}$ solution for modeling of lake water from Nordic countries. The water colour was about $60 \mathrm{mg} \mathrm{Pt} / 1$. Two types of adsorbents were used, especially synthesized ferric oxyhydroxide and powdered birch activated carbon.

Colloidal fouling was modeled by the usage of starch solution in the concentration of $0.00015 \%$. Cellulose acetate membrane filter with pore size of $0.45 \mu \mathrm{m}$ was used as a microfiltration membrane. After backwash residual starch was detected by iodine colouring. The water from Dnipro river was used for testing of hybrid method on the real water. Water was mixed with ferric oxyhydroxide

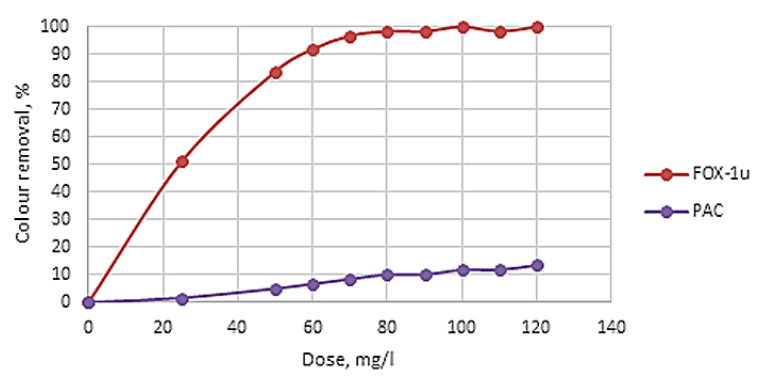

Figure 1. Colour removal for various doses suspension and separated by fixed in filter holder membrane filter. Such parameters as colour, UV-254, $\mathrm{pH}$ and others were measured in filtrate. Total arsenate and phosphate concentration was detected photometrically as a blue compound of redoxing of heteropoly acids (Litynska et al, 2017).

\section{RESULTS AND DISCUSSIONS}

The synthesized adsorbent particles had sizes in the range $0.5-3.0 \mu \mathrm{m}$, the diameters of the main part were about $1 \mu \mathrm{m}$. According to the X-ray diffractograms, $\mathrm{FeOOH}$ was the predominant phase. The model water had colour about $60 \mathrm{mg} \mathrm{Pt} / 1$ and $\mathrm{pH}$ about 5.8. Suspension of ferric oxyhydroxide (FOX-1u) and powdered activated carbon (PAC) were used as adsorbents. Two kinds of dependencies were discovered, for example, colour removal $=\mathrm{f}($ adsorbent dose $)$ and colour removal $=$ $\mathrm{f}$ (adsorption time) (Figures 1-2). Figure 1 showed the relations between the dose and removal efficiency. Duration of adsorption on the shaker was 5 hours for reaching of the equilibrium. Adsorbent doses were from 25 to $120 \mathrm{mg}$ of dry sorbent/l.

According to the EU regulations, the maximum colour of drinking water was $20 \mathrm{mg} \mathrm{Pt} / \mathrm{l}$, but the desired level was $5 \mathrm{mg} \mathrm{Pt} / 1$. Ferric oxyhydroxide needed doses $40 \mathrm{mg} / \mathrm{l}$ for allowable colour $(20 \mathrm{mg} \mathrm{Pt} / \mathrm{l})$ and $60 \mathrm{mg} / \mathrm{l}$ for desired colour $(5 \mathrm{mg} \mathrm{Pt} / \mathrm{l})$ in the case of 5 hour sorption, while powdered activated carbon did not reach these levels at the discovered range of doses. Figure 2 described influence of adsorption duration on the removal efficiency. In the case of this dependency, the adsorbent dose was $110 \mathrm{mg} / \mathrm{l}$.

Iron (III) oxyhydroxide reached allowable and desired removal efficiency after 4 and 6 minutes respectively, while powdered activated carbon did not measure up the allowable removal efficiency. Starch solution was chosen for fouling experiments due to its easy detection and ability

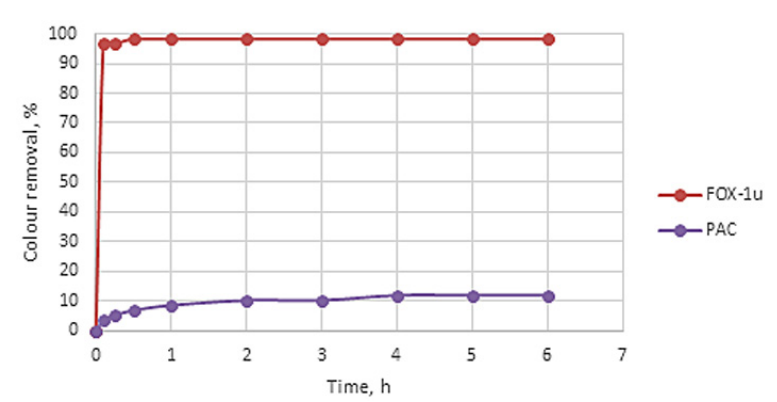

Figure 2. Colour removal for different durations 
to form gel layer. Three regimes were discovered, especially, usage of membrane without adsorbent, usage of membrane with inflicted adsorbent layer, filtration of water-adsorbent mixture throw membrane (Figures 3-5). Figure 3 showed the principal model of filtration of water with high organics content through microfiltration or ultrafiltration membrane.

The first stage described entering of untreated water to the membrane. The second stage illustrated filtration through microfiltration membrane. Highly-molecular organic matter formed a gel layer on the membrane surface and clogged the pores. Lowly-molecular substances and different ions, for example arsenates, leaked through the microfiltration membrane. Therefore, the treatment efficiency was insufficient. Water after membrane had high colour and arsenate removal was approximately zero. Backwash was the third stage. The main part of the formed gel layer could not be removed by simple backwash due to the adhesion of natural organic matter to the membrane. Figure 4 described filtration through a membrane with inflicted adsorbent layer.

Before treatment, a portion of the diluted adsorbent suspension went to the membrane and formed protective thickness under pressure. The first stage showed entering of raw water to the membrane with fixed adsorbent layer. Water treatment was the second step. Such impurities as arsenates, absorbed on the ferric oxyhydroxide particles. The arsenate ions were smaller than the pore size of membranes, but the adsorbent particles had larger diameter than pores. Hence, the arsenic compounds were immobilized in the form of insoluble ferric arsenate on the surface of adsorbent particles, which were separated from the water due to the size difference. Organic components formed gel thickness atop the sorbent layer. The third stage illustrated membrane cleaning due to backwash process. A gel layer adhered to the adsorbent cover. Thus, during backwash, organics were removed with ferric oxyhydroxide particles. Figure 5 showed filtration of adsorbentwater mixture through a membrane.

Mixing of raw water and ferric oxyhydroxide was the first stage. The second step described the interaction between the adsorbent particles and impurities. Arsenates were immobilized on the particle surface due to formation of insoluble ferric arsenate. The phosphate removal mechanism was the same. Part of natural organic matter was adsorbed and other part was in solution because
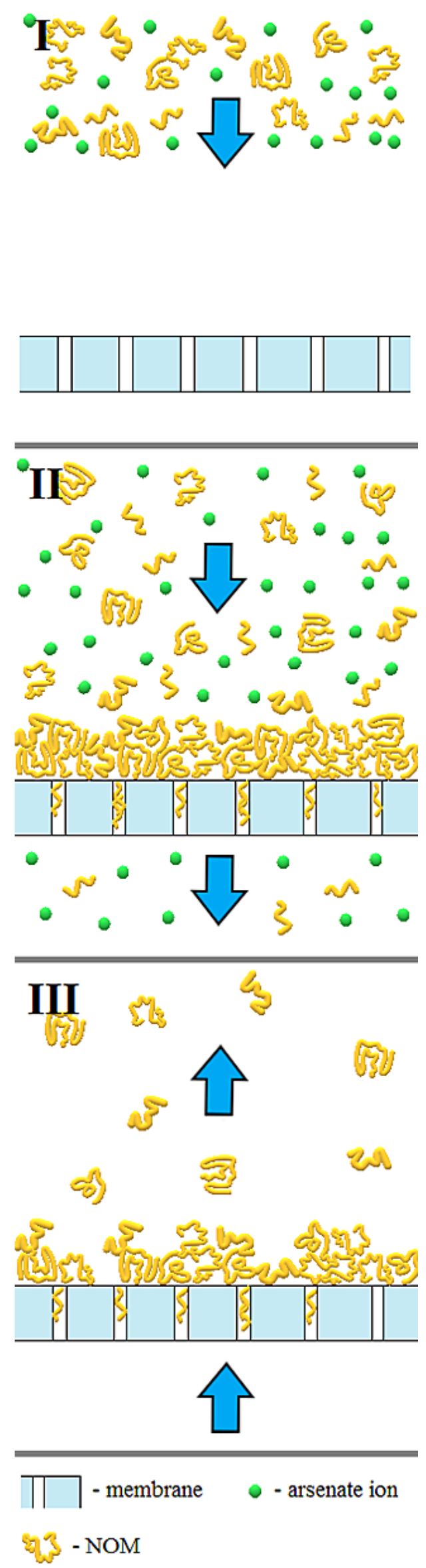

Figure 3. Process of membrane fouling 


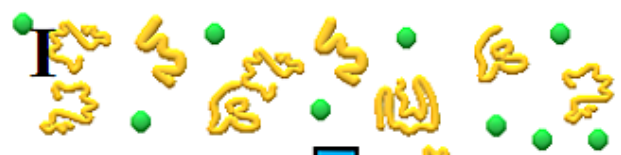

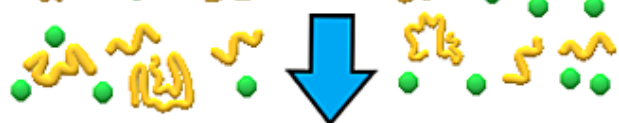
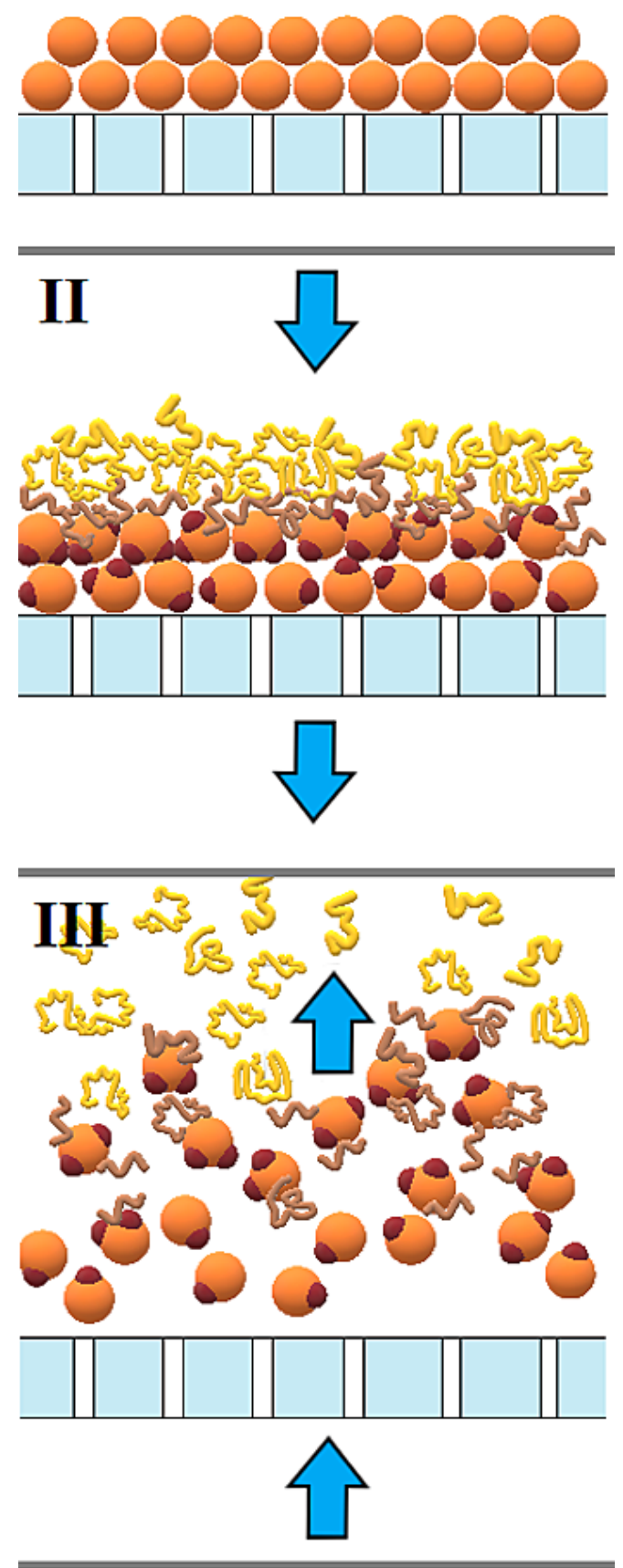

$\prod$ - membrane $\bigcirc$ - adsorbent particle

$$
\begin{aligned}
& 53 \text { - NOM } 53 \text { - adsorbed NOM } \\
& \text { - - arsenate ion - - ferric arsenate }
\end{aligned}
$$

Figure 4. Fouling prevention by adsorbent layer
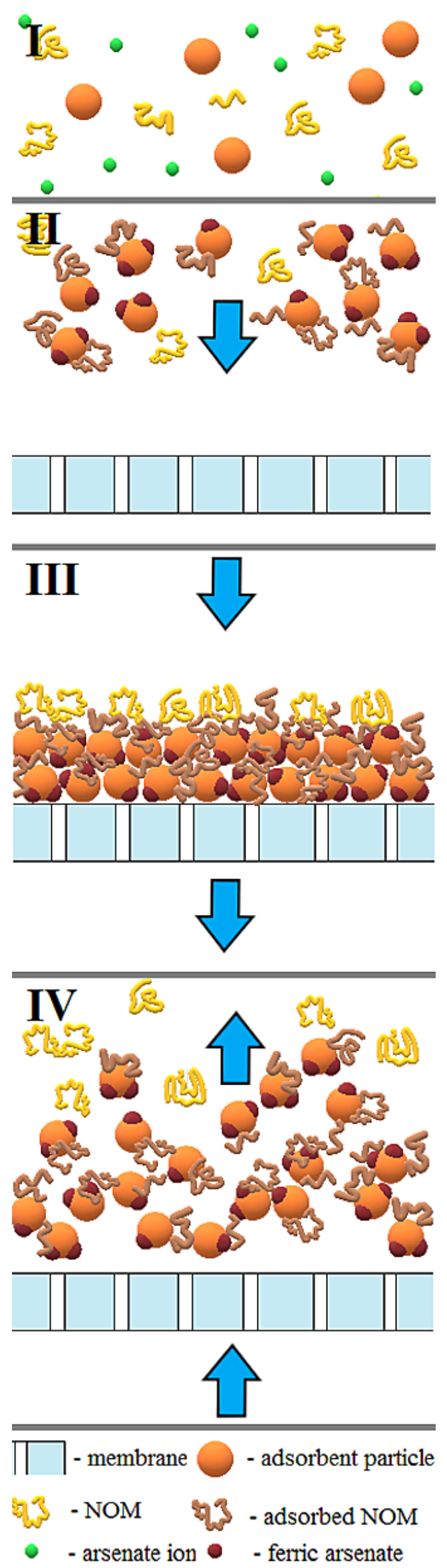

Figure 5. Hybrid adsorption/microfiltration method 
these organics had different properties. Separation was the third step. Adsorbent with immobilized impurities formed a protective layer on the membrane surface. The non-adsorbed organic matter was left on this thickness. Backwash was the fourth stage. Water flow removed the adsorbent with immobilized pollutants. Afterwards, membrane was as clean as before filtration. Figure 6 demonstrated the efficiency of protective adsorbent layer.

Colloidal fouling was modeled by the usage of starch solution in the concentration of $0.00015 \%$. Cellulose acetate membrane filter with pore size of $0.45 \mu \mathrm{m}$ was used as a microfiltration membrane. After backwash, residual starch was detected by iodine colouring. Starch formed the gel layer on the membrane surface, which could not be removed during backwash (Figure 6a). After iodine colouring, this thickness became blue (Figure 6b). Hence, fouling was really easily detected. In the case of adsorbent protection, starch did not form a gel layer on the membrane, only on the thickness of ferric oxyhydroxide. Therefore, iodine colouring of the membrane after backwash did not give blue colour (Figure 6d). Synthesized ferric oxyhydroxide was effective as reagent for prevention of colloidal fouling. Filtration velocity dramatically decreased during membrane filtration due to the formation of a resistant gel layer. In this case, backwash did not give a significant effect because starch adhered to the membrane surface.

Both methods of ferric oxyhydroxide usage demonstrated a positive result on fouling prevention. However, the filtration of adsorbent-water mixture through a membrane was more effective than the filtration through a membrane filter with inflicted adsorbent layer, because at the beginning of the process, the membrane with fixed ferric oxyhydroxide had a higher flow resistance than a single membrane. Moreover, formation of an organic layer on the adsorbent thickness significantly decreased the filtration velocity. The initial filtration velocity for membrane with inflicted adsorbent was $0.736 \mathrm{~m} / \mathrm{h}$ and decreased about twice after 2.5 minutes of filtration of model water with the starch concentration of $0.00015 \%$. In the case of mixed process, NOM molecules were adsorbed on the ferric oxyhydroxide particles and did not decrease the velocity due to formation of gel layer. Resistance grew up only due to increasing of sorbent thickness on the membrane. Initial filtration velocity for experiment with mixing stage was $1.302 \mathrm{~m} / \mathrm{h}$ and decreased about twice after $3 \mathrm{~min}$ utes of filtration of starch solution in the concentration of $0.00015 \%$. Starch-based model water contained higher quantity of fouling components, so clogging was significantly quicker than for natural waters. Thus, in terms of colloidal fouling protection the recommended regime was dividing of adsorption and microfiltration in two stages. Mixing with adsorbent was the first one and separation on the membrane was the second one.

The water from Dnipro river was used for testing the hybrid method on real water. The water was sampled in Kyiv on 05.06.2018. Figure 7 illustrated the choice of mixing duration.

Dearsenication was more important than natural organic matter removal due to the high toxicity of arsenic compounds. In general, the surface water in Kyiv had about $30 \mu \mathrm{g} / \mathrm{l}$ of total arsenic. However, the arsenates and phosphates removal had the same mechanisms and there was contention between these ions. Thus, determination of total content of these ions was relevant. The adsorbent dose was $110 \mathrm{mg}$ of dry sorbent/1. According to the Figure 7, $30 \mathrm{~min}$ utes was enough for arsenates and phosphates removal. Thus, next experiments had duration of the mixing stage 30 minutes. Table 1 showed

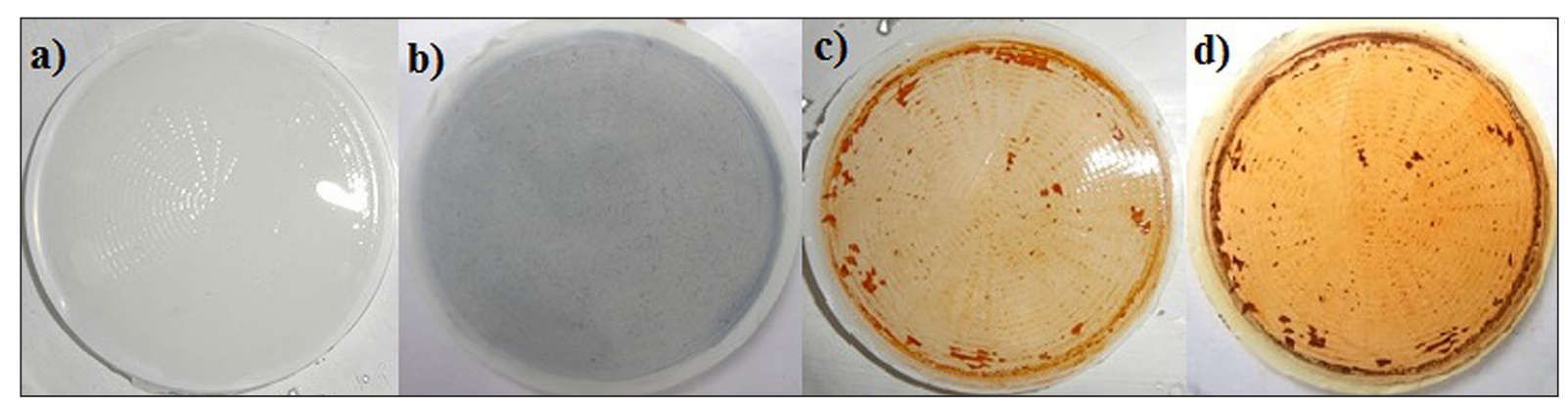

Figure 6. Prevention of colloidal fouling:

a) membrane filter after backwash (without adsorbent protection); b) membrane filter after backwash (without adsorbent protection) coloured by iodine solution; c) membrane filter after backwash (with adsorbent protection); d) membrane filter after backwash (with adsorbent protection) coloured by iodine solution 


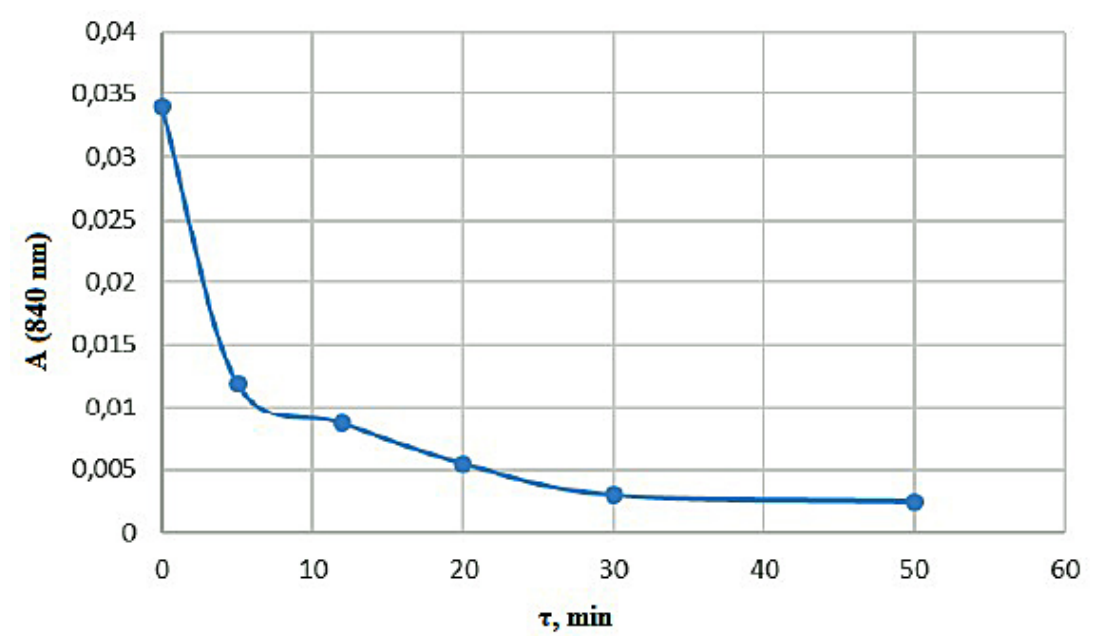

Figure 7. Influence of mixing time on total removal of phosphates and arsenate

the relations between adsorbent dose and parameters of the treated water

Three adsorbent dosages (50, 110 and $150 \mathrm{mg} / \mathrm{l})$ were tested. Even $50 \mathrm{mg} / \mathrm{l}$ was very effective in the removal of arsenates and phosphates. The purification efficiency increased rapidly to the dose $110 \mathrm{mg} / \mathrm{l}$, whereas in the range of $110-150 \mathrm{mg} / \mathrm{l}$ there was a much less intensive process. The dose of $110 \mathrm{mg} / \mathrm{l}$ was sufficient for the virtually complete removal of inorganic compounds of arsenic and phosphorus from water. The organic matter for this dose was removed only by half. At the dose of $150 \mathrm{mg} / 1$ reducing was almost two thirds. Thus, in the beginning the removal of arsenates and phosphates took place due to the formation of insoluble ferric compounds. The chemisorption processes occurred. The NOM removal was significantly slower. As a result, there was $\mathrm{pH}$ increasing of water after treatment with growing of sorbent doses, so we could assume

Table 1. Treatment efficiency for three adsorbent doses

\begin{tabular}{|c|c|c|c|}
\hline Adsorbent dose, mg/l & 50 & 110 & 150 \\
\hline $\mathrm{A} / \mathrm{A}_{0}(840 \mathrm{~nm})$ & 0.284 & 0.088 & 0.069 \\
\hline$A_{\text {residual }}(840 \mathrm{~nm})$ & 0.010 & 0.003 & 0.002 \\
\hline $\mathrm{A} / \mathrm{A}_{0}(450 \mathrm{~nm})$ & 0.636 & 0.517 & 0.379 \\
\hline $\mathrm{A} / \mathrm{A}_{0}(254 \mathrm{~nm})$ & 0.881 & 0.787 & 0.721 \\
\hline pH after adsorption & 8.05 & 8.12 & 8.15 \\
\hline Change of $\mathrm{pH}$ & 0.29 & 0.36 & 0.39 \\
\hline $\begin{array}{l}\text { Alkalinity after adsorption, } \\
\mathrm{mmol} / \mathrm{l}\end{array}$ & 3.4 & 3.8 & 4.4 \\
\hline Change of alkalinity, mmol/l & 0.0 & 0.4 & 1.0 \\
\hline Filtration velocity, $\mathrm{m} / \mathrm{h}$ & 4.08 & 2.60 & 1.88 \\
\hline $\mathrm{COD}$ after adsorption, $\mathrm{mg} \mathrm{O}_{2} / \mathrm{l}$ & 24 & 16 & 12 \\
\hline Change of COD, $\mathrm{mg} \mathrm{O}_{2} / \mathrm{l}$ & 32 & 40 & 44 \\
\hline
\end{tabular}

that treatment had ion exchange mechanism, in which $\mathrm{OH}^{-}$ions came to the liquid phase and it led to increasing the $\mathrm{pH}$. Moreover, total iron content in water dramatically dropped after treatment and became lower than the legislative level.

Different natures of NOM could be the reason of insufficient removal of organic matter. Natural organic matter could be hydrophobic or hydrophilic, have negative, neutral or positive charge, etc. Thus, ferric oxyhydroxide was not effective for all types of NOM. In the case of high organic content, application of adsorbents mixtures was recommended, for example, suspension of ferric oxyhydroxide and powdered activated carbon. According to the table 1 , coloured compounds (humates) $(450 \mathrm{~nm})$ were removed better than uncoloured or slightly coloured other organics having a benzene ring in its structure $(254 \mathrm{~nm})$. It was confirmed that the ferric oxyhydroxide was selective in relation to the anions.

\section{CONCLUSIONS}

1. Membrane technologies are very popular both in drinking water and wastewater treatment due to their significant advantages, for example, high process automatization, small physical footprint, high efficiency, simple maintenance, etc. However, this treatment method has some disadvantages, especially fouling. There are different kinds of fouling, but colloidal fouling is the most unacceptable type. Fine particle ferric oxyhydroxide effectively protected membrane and adsorb humates, phosphates, arsenates, etc. 
2. Both methods of usage of ferric oxyhydroxide demonstrated a positive result on fouling prevention. However, filtration of adsorbent-water mixture through membrane was more effective than filtration through membrane filter with inflicted adsorbent layer, because in the beginning of the process, the membrane with fixed ferric oxyhydroxide had higher flow resistance than a single membrane. Moreover, formation of organic layer on the adsorbent thickness significantly decreased the filtration velocity. In the case of mixed process, the NOM molecules were adsorbed on the ferric oxyhydroxide particles and did not decrease the velocity due to the formation of a gel layer. Resistance grew up only due to increasing of the sorbent thickness on the membrane. Thus, in terms of colloidal fouling, protection recommended regime was dividing of adsorption and microfiltration in two stages. Mixing with adsorbent was the first one and separation on the membrane was the second one.

3. Consequently, the proposed sorption membrane method allowed easy and efficient normalization of arsenic, phosphate, iron level and in the case of high doses, it significantly decreases the colour of water to the normative value. Additionally, the use of this sorbent increased the $\mathrm{pH}$ of water, which, according to the Langelier saturation index, reduced the probability of corrosion of the pipelines and made the water more organoleptically pleasant.

\section{REFERENCES}

1. Blandin, G., Vervoort, H., Le-Clech, P., \& Verliefde, A. R. D. 2016. Fouling and cleaning of high permeability forward osmosis membranes. Journal of Water Process Engineering, 9, 161-169. http://doi. org/https://doi.org/10.1016/j.jwpe.2015.12.007.

2. Cai, Z., Wee, C., \& Benjamin, M. M. 2013. Fouling mechanisms in low-pressure membrane filtration in the presence of an adsorbent cake layer. Journal of Membrane Science, 433, 32-38. http://doi. org/10.1016/j.memsci.2013.01.007.

3. Fane, A. G., Wang, R. and Hu, M. X. 2015. Synthetic Membranes for Water Purification: Status and Future. Angew. Chem. Int. Ed., 54: 3368-3386. doi:10.1002/anie.201409783.

4. Kim, J., Cai, Z., \& Benjamin, M. M. 2008. Effects of adsorbents on membrane fouling by natural organic matter. Journal of Membrane Science, 310(1-2), 356-364. http://doi.org/10.1016/j.memsci.2007.11.007.
5. Kim, J., Deng, Q., \& Benjamin, M. M. 2008. Simultaneous removal of phosphorus and foulants in a hybrid coagulation/membrane filtration system. Water Research, 42(8-9), 2017-2024. http://doi. org/10.1016/j.watres.2007.12.017.

6. Kleber, M., Eusterhues, K., Keiluweit, M., Mikutta, C., Mikutta, R., \& Nico, P. S. 2015. Chapter One - Mineral-Organic Associations: Formation, Properties, and Relevance in Soil Environments. In D. L. Sparks (Ed.) (Vol. 130, pp. 1-140). Academic Press. http://doi.org/https://doi.org/10.1016/ bs.agron.2014.10.005.

7. Litynska, M \& Maletskyi, Z. 2017. Characterization of iron-based fine particle adsorbents. Book of abstracts of III Ukrainian-Polish scirntific conference "Membrane and sorption processes and technologies", pp. 167-169.

8. Litynska, M., Antoniuk, R., Tolstopalova, N., \& Astrelin, I. 2017. Powder iron-containing adsorbents for arsenic removal: influence of heating. Process Eng. J., 1(2), 68-72.

9. Litynska, M., Antoniuk, R., Tolstopalova, N., \& Astrelin, I. 2018. Method of synthesis of fine-particle iron (III) oxyhydroxide for combined sorptionmembrane water treatment technology. Patent UA 123917 U, pp. 1-4 (in Ukrainian).

10. Liu, T., Yang, B., Graham, N., Lian, Y., Yu, W., \& Sun, K. 2017. Mitigation of NOM fouling of ultrafiltration membranes by pre-deposited heated aluminum oxide particles with different crystallinity. Journal of Membrane Science, 544, 359-367. http://doi.org/https://doi.org/10.1016/j.memsci.2017.09.048.

11. Pivokonsky, M., Safarikova, J., Baresova, M., Pivokonska, L., \& Kopecka, I. 2014. A comparison of the character of algal extracellular versus cellular organic matter produced by cyanobacterium, diatom and green alga. Water Research, 51, 37-46. http://doi.org/https://doi.org/10.1016/j.watres.2013.12.022.

12. Radaei, E., Liu, X., Tng, K. H., Wang, Y., Trujillo, F. J., \& Leslie, G. 2018. Insights on pulsed bubble control of membrane fouling: Effect of bubble size and frequency. Journal of Membrane Science, 554, 59-70. http://doi.org/https://doi.org/10.1016/j. memsci.2018.02.058.

13. Rosario-Ortiz, F. L., Snyder, S. A., \& Suffet, I. H. (Mel). 2007. Characterization of dissolved organic matter in drinking water sources impacted by multiple tributaries. Water Research, 41(18), 41154128. http://doi.org/https://doi.org/10.1016/j.watres.2007.05.045.

14. She, Q., Wang, R., Fane, A. G., \& Tang, C. Y. 2016. Membrane fouling in osmotically driven membrane processes: A review. Journal of Membrane Science, 499, 201-233. http://doi.org/https://doi. org/10.1016/j.memsci.2015.10.040. 
15. Shi, W., \& Benjamin, M.M. 2009. Fouling of RO membranes in a vibratory shear enhanced filtration process (VSEP) system. Journal of Membrane Science, 331(1-2), 11-20. http://doi.org/10.1016/j. memsci.2008.12.027.

16. Siddiqui, A., Lehmann, S., Bucs, S.S., Fresquet, M., Fel, L., Prest, E.I.E.C., Vrouwenvelder, J.S. 2017. Predicting the impact of feed spacer modification on biofouling by hydraulic characterization and biofouling studies in membrane fouling simulators. Water Research, 110, 281287. http://doi.org/https://doi.org/10.1016/j.watres.2016.12.034.

17. Sim, S.T.V, Taheri, A.H., Chong, T.H., Krantz,
W.B., \& Fane, A.G. 2014. Colloidal metastability and membrane fouling - Effects of crossflow velocity, flux, salinity and colloid concentration. Journal of Membrane Science, 469, 174-187. http://doi. org/https://doi.org/10.1016/j.memsci.2014.06.020.

18. Su, X., Li, W., Palazzolo, A., \& Ahmed, S. 2018. Concentration polarization and permeate flux variation in a vibration enhanced reverse osmosis membrane module. Desalination, 433, 75-88. http://doi. org/https://doi.org/10.1016/j.desal.2018.01.001.

19. Sun, W., Liu, J., Chu, H., \& Dong, B. 2013. Pretreatment and membrane hydrophilic modification to reduce membrane fouling. Membranes, 3(3), 226241. http://doi.org/10.3390/membranes3030226. 